\title{
OPTIMIZING THE PRODUCTION OF A FUNCTIONAL TYPE A RECOMBINANT ENDOCHITINASE FROM Trichoderma asperellum IN Escherichia coli
}

\section{Nguyen Ngoc Luong ${ }^{3}$ (D), Nguyen Quang Duc Tien ${ }^{3}$ (D), Phung Thi Bich Hoa ${ }^{2}$, Nguyen Hoang Tue ${ }^{3}$, Mai Thi Thu Hien ${ }^{4}$, Nguyen Hoang Loc ${ }^{3, *(D)}$, Nguyen Xuan Huy ${ }^{1,2, *(D)}$}

${ }^{1}$ Department of Science, Technology and International Relations, Hue University, 03 Le Loi, Hue 530000, Vietnam.

${ }^{2}$ Department of Biology, University of Education, Hue University, 32 Le Loi, Hue 530000, Vietnam.

${ }^{3}$ Institute of Bioactive Compounds and Department of Biotechnology, University of Sciences, Hue University, 77 Nguyen Hue, Hue 530000 , Vietnam.

${ }^{4}$ Le Loi Secondary School, 07 Ho Xuan Huong, My An, Ngu Hanh Son, Danang 550000, Vietnam.

Received - November 16, 2021; Revision - December 01, 2021; Accepted - December 19, 2021

Available Online - December 30, 2021

DOI: http://dx.doi.org/10.18006/2021.9(6).871.880

\section{KEYWORDS}

Trichoderma asperellum

Chitinase

Soluble protein

E. coli

Induction temperature

\begin{abstract}
Chitinases from the genus Trichoderma fungi are mainly responsible for their anti-fungal activities, which allow them to become the most widely used fungal biocontrol. Therefore, several Trichoderma chitinases have been cloned and expressed to facilitate their production and applications. A previous study of the same authors has characterized an endochitinase from a relatively novel Trichoderma spp., Trichoderma asperellum. To produce this enzyme more economically and efficiently, we reported the synthesis and expression of its synthetic encoding gene in the Escherichia coli M15 strain and established the optimal conditions for preparative scale production of the enzyme in its functional form. By lowering the induction temperatures, we observed substantial improvement in the expression levels of the active enzyme. At $30{ }^{\circ} \mathrm{C}$ and $0.5 \mathrm{mM}$ IPTG induction, $1 \mathrm{~L}$ of cells yielded approximately 80 $100 \mathrm{mg}$ of soluble protein, accounting for about 9-11\% of total soluble protein. This figure may be an underestimation of the actual yield, as deduced from the SDS-PAGE data. The recombinant enzyme can be retrieved by simple repeated freezing and thawing cycles and purified to near homogeneity using NiNTA chromatography. The purified enzyme showed in vitro colloidal chitin hydrolysis activity. These results could be scaled up to produce soluble $42 \mathrm{kDa}$ chitinase in E. coli. The study demonstrated an economical method to produce chitinases for various agricultural and environmental applications.
\end{abstract}

\section{* Corresponding author}

E-mail: nhloc@hueuni.edu.vn (Nguyen Hoang Loc); nguyenxuanhuy@hueuni.edu.vn (Nguyen Xuan Huy)

Peer review under responsibility of Journal of Experimental Biology and Agricultural Sciences.

Production and Hosting by Horizon Publisher India [HPI] (http://www.horizonpublisherindia.in/).

All rights reserved.
All the articles published by Journal of Experimental Biology and Agricultural Sciences are licensed under a Creative Commons Attribution-NonCommercial 4.0 International License Based on a work at www.jebas.org.

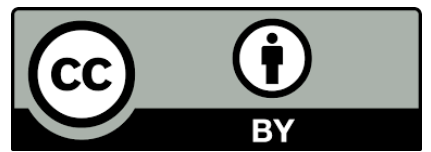




\section{Introduction}

Chitin and cellulose are the two most abundant polymers on earth. Chitin is commonly found in fungi, insects, crustaceans' shells and is the most abundant amino-polysaccharide polymer occurring in nature. Chitinases can break down chitin to chitosan, which finds its extreme popularity in biomedical material applications (Ramli et al., 2011; Fenta et al., 2020; Poveda et al., 2020; Sood et al., 2020) as well as pharmaceutical, cosmetics, agricultural, food, environmental applications (Morin-Crini et al., 2019).

The genus Hypocrea/Trichoderma are famous mycoparasites that aggressively attack other fungi through their diverse array of chitinases (Seidl-Seiboth et al., 2014). The chitinases are responsible for their cell wall remodeling as well as degrading other fungi for food sources. Trichoderma, particularly $T$. harzianum $\mathrm{T}-22$, has become the most successful biocontrol agent to date, with superior anti-fungal activity compared to commercial chemicals while being more environmentally friendly (Harman, 2000). T-22 can be used to protect seed and seedlings, which significantly improves germination (Mastouri et al., 2010). T-22 can also reduce root, flower, and fruit diseases caused by fungi, insects, or parasites. More importantly, T-22 has been shown to have other beneficial effects on crops through abiotic and physiological stress reduction, nutrient uptake enhancement, and nitrogen use efficiency (Shoresh et al., 2010).

Due to their prominent roles as biocontrol agents, Trichoderma chitinases are very much sought after. Several studies have attempted to produce Trichoderma chitinases through recombinant DNA technology as an alternative to natural sources (Sharma, 2012; Zeng et al., 2016; Deng et al., 2019). Earlier, Ike et al. (2006) studied and expressed a $46 \mathrm{kDa}$ chitinase from $T$. reesei in E. coli and Klemsdal et al. (2006) studied a novel, 30 $\mathrm{kDa}$ chitinase from $T$. atroviride $\mathrm{P} 1$, then produced its recombinant form in $E$. coli to facilitate its characterization. Other groups expressed Trichoderma chitinases in yeasts (Draborg et al., 1996; Jinzhu et al., 2005). Recombinant chitinases may find their use as biocontrol agents to prevent refrigerated food spoilage (Ramli et al., 2011) or additives in pharmaceutical production (Hamid et al., 2013).

Our previous studies have characterized a $42 \mathrm{kDa}$ chitinase from a relatively less well-known member of the genus Trichoderma, T. asperellum (Loc et al., 2011), and subsequently cloned and expressed it in S. cerevisiae (Loc et al., 2013). However, the secretion of the recombinant enzyme was not ideal due to the presence of an intron as well as the native signal peptide in the encoding gene. To obtain this enzyme for applications such as food spoilage or hydroponic fertilizers, in this study, we reported the redesign of the gene, its expression, and purification in $E$. coli with positive results that warrant a follow-up study of its production and applications. The current study also attempted to develop a simple procedure for optimizing the yield of the functional enzyme.

\section{Materials and methods}

\subsection{Strains and culture conditions}

E. coli TOP10 strain was maintained in Luria Broth (LB) plates and liquid medium without antibiotics. E. coli M15 strain (Qiagen, F- $\Phi 80 \Delta \mathrm{lacM} 15$, thi, lac- $m t l-, \quad r e c A+, \mathrm{Km}^{\mathrm{R}}$ ) was maintained in LB media supplemented with $50 \mu \mathrm{g} / \mathrm{ml}$ Kanamycin (Duchefa) (Nguyen et al., 2013). The M15 strain transformed with a recombinant $\mathrm{pQE30}$ vector was maintained in LB media supplemented with $50 \mu \mathrm{g} / \mathrm{ml}$ Kanamycin and $50 \mu \mathrm{g} / \mathrm{mL}$ Ampicillin (QIAGEN's QIA expressionist $5^{\text {th }}$ edition, 2003). Cells were cultured and induced in LB liquid media supplemented with appropriate antibiotics on a shaking incubator at $220 \mathrm{rpm}$.

\subsection{Design and synthesis of the encoding gene}

To ensure that the target protein is free from any sequence errors, we first used our original deduced protein sequence (ADI46582.1) (Loc et al., 2011) as the query sequence and searched for similar sequences on the NCBI Genpept database by BLASTP, then aligned all the subject sequences that have their identity equal or greater than $98 \%$ with the query sequence. To obtain the consensus sequence, the multiple alignment result was put through EMBOSS cons software (https://www.bioinformatics.nl/cgibin/emboss/ cons). Subsequently, the consensus protein sequence was queried against the Genbank database using tBLASTN to find the gene that encodes for such a consensus sequence (HM191683.1). The coding sequence of this gene (excluding the signal peptide sequence), termed as $w C H I 42$, was determined and the gene product was synthesized by Phusa Biochem LTD company to contain a BamHI and SacI at 5' and 3' termini, respectively. In addition, an internal SacI recognition site was removed from the coding sequence by synonymous codon substitution (Leu330: CTC converted to CTT). The gene was cloned into the pUC19 vector, and its sequence was confirmed by Sanger's sequencing (Phusa Biochem LTD company).

\subsection{Construction of the expression cassette}

The $w_{C H I}$ gene was released from pUC19 by BamHI/SacI double digestion and ligated into the pQE30 (QIAGEN's QIA expressionist $5^{\text {th }}$ edition, 2003), which was already linearized by the same pair of restriction enzymes. The resulting recombinant plasmid, termed pQE30-wCHI42, was confirmed to have the correct reading frame and is free from sequence errors by Sanger's sequencing (First BASE Laboratories). 


\subsection{Transformation and expression analysis}

pQE30-wCHI42 was transformed into E. coli M15 strains by chemical transformation. Putative transformants were transferred to a replica LB plate containing Kanamycin and Ampicillin (QIAGEN's QIA expressionist $5^{\text {th }}$ edition, 2003). Six transformants were randomly selected and analyzed for CHI42 expression by SDSPAGE. To do this, we first inoculated the selected into $5 \mathrm{~mL} \mathrm{LB}$ containing the appropriate antibiotics and cultured overnight (ON) on a shaking incubator at $37{ }^{\circ} \mathrm{C}$, and $220 \mathrm{rpm}$. The next day, $100 \mu \mathrm{L}$ of each $\mathrm{ON}$ culture was added into $10 \mathrm{ml}$ of freshly prepared $\mathrm{LB}$ with the antibiotics, and the freshly inoculated cultures were grown at $37{ }^{\circ} \mathrm{C}, 220 \mathrm{rpm}$ until ODs reached 0.7-0.8. Induction was carried out using $0.5 \mu \mathrm{M} / \mathrm{mL}$ IPTG at $37{ }^{\circ} \mathrm{C}$ for 4 hours based on the manufacturer's recommendation (Qiagen). An equal amount of cells was collected before and at the end of the induction period, spun to remove media, and resuspended into $10 \mu \mathrm{L}$ of $\mathrm{dH}_{2} \mathrm{O}$. An equal volume of 6x SDS-PAGE loading buffer was added and the cells were lysed at $100{ }^{\circ} \mathrm{C}$ by boiling for 10 minutes. The lysates were analyzed on $12 \%$ discontinuous SDS-PAGE gel and the gel was stained with Coomassie blue to enable visualization of protein bands. Cells from before and at the end of the induction period for each clone were analyzed side by side and the appearance of a strong band at approximately $40-45 \mathrm{kDa}$ in the induced sample but not in the before induced sample indicates successful expression of CHI42. From these results, two clones with the highest expression level were selected for storage and subsequent analysis (Kim et al., 2009).

\subsection{SDS-PAGE and Western blot analysis}

A discontinuous SDS-PAGE gel system was used throughout the study to analyze the expression and purification of CHI42 (Huy et al., 2016). The gel was made up of a $12 \%$ separating gel stacked on top by a $5 \%$ stacking gel and was cast by Biorad mini-PROTEAN Tetra handcast system. Protein samples' concentrations were determined by Bradford assay to ensure equal amounts were loaded on each well. Samples were mixed with $6 x$ protein loading buffer and boiled for 10 minutes at $100{ }^{\circ} \mathrm{C}$ before loading. Gels were first to run at $60 \mathrm{~V}$ for 30 minutes, followed by $100-120 \mathrm{~V}$ until the dye front ran off the gel. Gels were blotted onto a Nylon membrane (Amersham Biosciences) using Biorad Wet/Tank blotting system at $145 \mathrm{~mA}$ for three hours in cooling conditions. The membranes were first blocked with $5 \%(\mathrm{w} / \mathrm{v})$ skim milk in TBST buffer (0.1 M Tris $\mathrm{HCl} \mathrm{pH} \mathrm{7.5,} \mathrm{0.154M} \mathrm{NaCl,} \mathrm{and} 0.1 \% \mathrm{v} / \mathrm{v}$ Tween 20) for 1 hour, and then exposed to polyclonal antibodies against CHI42 (at 1:2000 dilution) for at least 1 hour at room temperature. After three washes with TBST, the membranes were incubated with AP-conjugated goat anti-mouse antibody (Abcam) for 2 hours. The membranes were washed three times with TBST, then equilibrated with TMN buffer (0.1M Tris $\mathrm{HCl} \mathrm{pH} 9.5,0.1 \mathrm{M} \mathrm{NaCl}$, and $0.005 \mathrm{M} \mathrm{MgCl}_{2}$ ) for 10 minutes. Subsequently, $2 \mathrm{ml}$ of premixed NBT/BCIP (Thermo Fisher
Scientific) was added, and the membranes were incubated in the dark until signals appeared (Nguyen et al., 2013).

\subsection{Temperature optimization for production of soluble CHI42 yield}

E. coli expressed CHI42 may end up mostly in inclusion bodies, therefore, we tested various expression temperatures to determine the temperature at which soluble CHI42 is highest. To do this, we induced a strain selected from the previous screening step at four different temperatures: $37{ }^{\circ} \mathrm{C}, 30^{\circ} \mathrm{C}, 20^{\circ} \mathrm{C}$, and $15{ }^{\circ} \mathrm{C}$ for 4 hours (San-Miguel et al., 2013). For each temperature, cells were collected at the end of the induction period. To obtain soluble proteins, cells were partially lysed by repeated cycles of freezing and thawing according to the procedure described by (Johnson \& Hecht, 1994). Equal amounts of induced cells and soluble fractions from each temperature were run side-by-side on SDS-PAGE. The intensity of CHI42 western blot bands was used to determine the relative amount of soluble CHI42 and its proportion to total CHI42 at different temperatures. ImageJ (Fiji) was used to determine the intensity of Western blot bands (Schindelin et al., 2012).

\subsection{Purification of soluble CHI42 and quantification}

After determining the temperature at which the yield of soluble CHI42 is highest, we proceeded to express CHI42 at a $2 \mathrm{~L}$ scale at that temperature. After the induction, cells were collected, washed with $\mathrm{dH}_{2} \mathrm{O}$, weighed, and stored at $-80{ }^{\circ} \mathrm{C}$. Frozen cells were taken out and lysed at $0^{\circ} \mathrm{C}$ using lysozyme $(1 \mathrm{mg} / \mathrm{mL})$ in phosphate buffer $\left(50 \mathrm{mM} \mathrm{NaH}{ }_{2} \mathrm{PO} 4,300 \mathrm{mM} \mathrm{NaCl}, 10 \mathrm{mM}\right.$ imidazole, $\mathrm{pH}$ 8.0 ) at $5 \mathrm{~mL}$ per gram wet weight (QIAGEN's QIAexpressionist $5^{\text {th }}$ edition, 2003). After incubating at $0{ }^{\circ} \mathrm{C}$ for 1 hour with continuous stirring, cells were further lysed by sonication (6x 10sec pulse). The clear lysate was separated from cell debris by centrifugation at $13.000 \mathrm{rpm}, 4{ }^{\circ} \mathrm{C}$. CHI42 was purified at $4{ }^{\circ} \mathrm{C}$ using Ni-NTA agarose packed into a poly-prep column (Biorad) (Kim et al., 2009). The conditions for the purification were: 10 $\mathrm{mM}$ imidazole for binding, $50 \mathrm{mM}$ imidazole for washing, and 250 $\mathrm{mM}$ imidazole for elution (QIAGEN's QIAexpressionist $5^{\text {th }}$ edition, 2003). Imidazole was eliminated from eluent fractions, and CHI42 was suspended in PBS (buffer exchange) by molecular weight cutoff centrifugal filters (Amicon, $10 \mathrm{kDa}$ cutoff). Purified soluble CHI42 was analyzed by Western blot using anti-CHI42 polyclonal antibodies as a probe (Luong et al., 2021).

To determine the yield of CHI42, we used quantitative ELISA with total soluble protein and purified CHI42 was used as the standard to construct a standard curve (OD405 vs. CHI42 amount). The amount of CHI42 in the measured samples at a specific dilution factor was determined by the standard curve. From this, CHI42 yield and its proportion to total soluble protein were determined. 


\subsection{Colloidal chitin hydrolysis assay}

The chitinolytic activity of the purified soluble $\mathrm{CH} 42$ was conducted using plate assay. A plate containing $1.5 \%$ agar and 1.2 $\%$ colloidal chitin (HiMedia Laboratories) was punched with three holes. The pre-punched holes were loaded with $30 \mu \mathrm{L}$ PBS containing $300 \mu \mathrm{g}$ of purified soluble CHI42 or control (cellular extract from pre-induced E. coli) and incubated at $4{ }^{\circ} \mathrm{C}$ for $8 \mathrm{hrs}$ for the enzyme to diffuse to the surrounding agar, and then at $28^{\circ} \mathrm{C}$ for $6 \mathrm{hrs}$ for chitinolysis. Finally, the plate was stained with $0.1 \%$ Lugol's solution to detect substrate hydrolysis (Luong et al., 2021). The experiment was repeated thrice and the diameters of hydrolysis rings were compared statistically.

\section{Results and Discussion}

\subsection{In silico analysis of the $T$. asperellum $42 \mathrm{kDa}$ chitinase}

Based on in silico analysis of CHI42, it is an endochitinase and belongs to GH 18 type A, subgroup Chi 18-11 (Seidl et al., 2005; Seidl-Seiboth et al., 2014), with a molecular weight of approximately $44.1 \mathrm{kDa}$ and $\mathrm{pI}$ of 5.02. Chitinases from group A usually have signal peptides but without carbohydratebinding modules. Figure 1 showed the schematic representation of ${ }_{\text {CHI42 }}$ and its phylogenetic relationship with endochitinases of the same subgroup from other Trichoderma species.

A

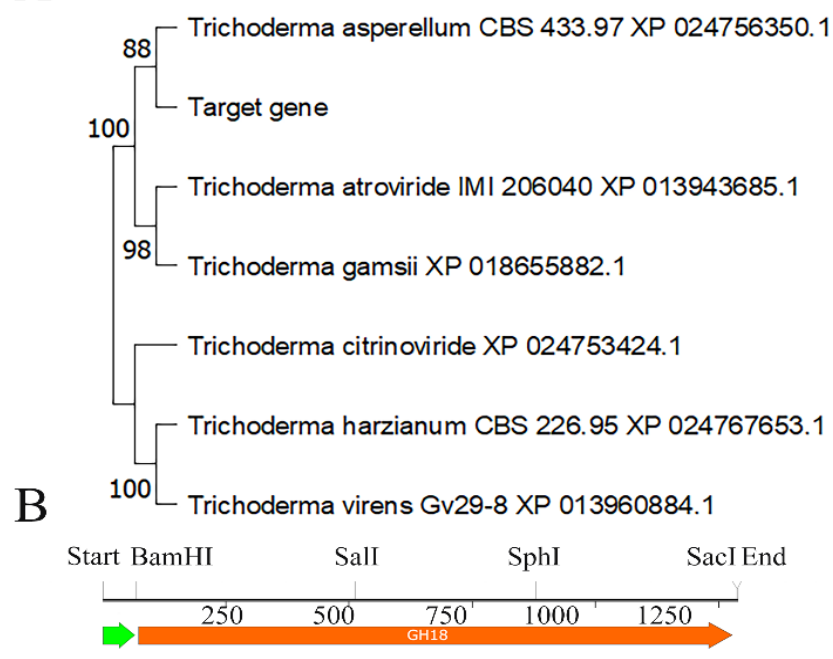

Signal peptide

Figure 1 (A) Phylogenetic relationship between T. asperellum CHI42 and other endochitinases found on NCBI genpept database. The tree was constructed by MEGA11 using the Maximum parsimony method with 2000 bootstrap tests.

(B) Schematic representation of $w$ CHI42 produced by snapgene
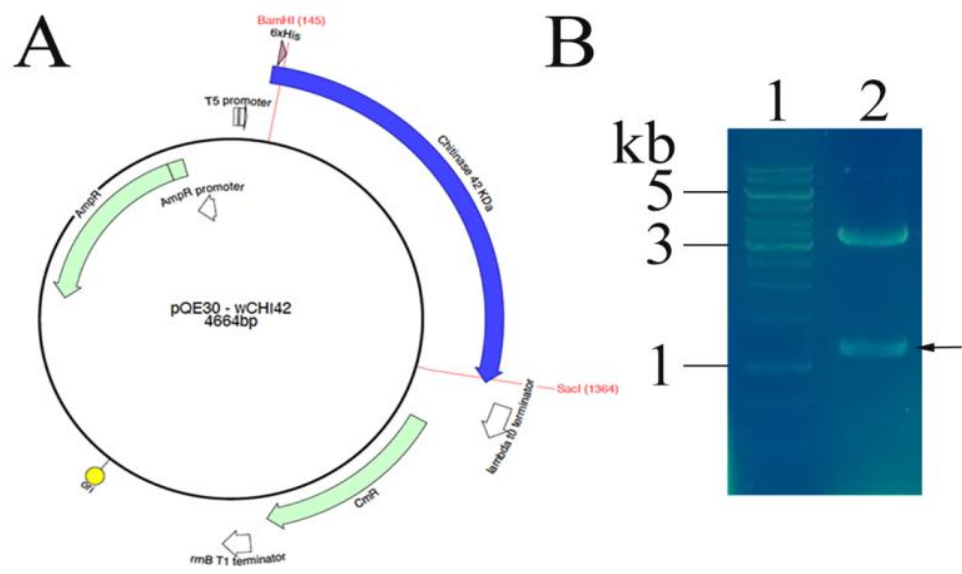

Figure 2 (A) Vector map shows pQE30-wCHI42 and (B) Restriction enzyme analysis of this recombinant plasmid on $1 \%$ agarose gel. The arrow indicates the $w C H I 42$ band, which is approximately $1.2 \mathrm{~kb}$

Journal of Experimental Biology and Agricultural Sciences http://www.jebas.org 


\subsection{Construction of the expression cassette}

The CHI42 CDS is approximately $1.2 \mathrm{~kb}$, containing a BamHI site at the 5' terminal, a stop codon followed by a SacI site at the 3' terminal. The recombinant vector pQE30-CHI42 is approximately $4.6 \mathrm{~kb}$ in size. Restriction digestion analysis of the vector with Bam HI/SacI yielded 2 bands of $1.2 \mathrm{~kb}$ and $3.4 \mathrm{~kb}$ (Figure 2). Sequencing the vector with primers flanking the insert confirmed the sequence identity with the theoretical sequence as well as the reading frame of the insert.

\subsection{Analysis of the expression of CHI42 in E. coli M15}

In a previous study using eGFP as a reporter gene, we observed some expression variation in putative transformant strains, which could be due to the heterogeneity of cells instead of variation in the vector copy number. Therefore, screening is needed to obtain robust transformants with stable, good expression (Trang et al., 2022). Screening of six randomly selected putative transformants showed that all of them successfully expressed CHI42, as indicated by the presence of a prominent band at approximately $45 \mathrm{kDa}$ in the induced cells but not in the non-induced cells. All eight transformants have roughly the same expression levels (data not shown); therefore, we selected randomly two out of eight for subsequent analysis.

At first, the M15 recombinant strains were induced with $0.5 \mu \mathrm{M}$ IPTG at $37{ }^{\circ} \mathrm{C}$ for 4 hours, according to the manufacturer's recommendation. However, upon enzyme activity analysis of the cell lysis solution, very little activity was detected. SDS-PAGE analysis of the cell lysates showed that the majority of the enzyme accumulated in inclusion bodies (data not shown). This was also observed with eGFP expression in the same strain (Trang et al., 2022).

With eGFP expression, we varied the expression temperature and observed an increase in the greenness intensity of $E$. coli cells with low temperatures (Trang et al., 2022). Based on this observation, we applied the same strategy to improve the solubility of CHI42 by lowering the induction temperature to $30{ }^{\circ} \mathrm{C}$. As expected, the number of soluble $\mathrm{CHI} 42$ at $30{ }^{\circ} \mathrm{C}$ induction improved significantly compared with $37{ }^{\circ} \mathrm{C}$ induction (Figure 3), though as much as half of the protein still ended up in the inclusion bodies, as indicated by the relative intensities of the Western blot bands.
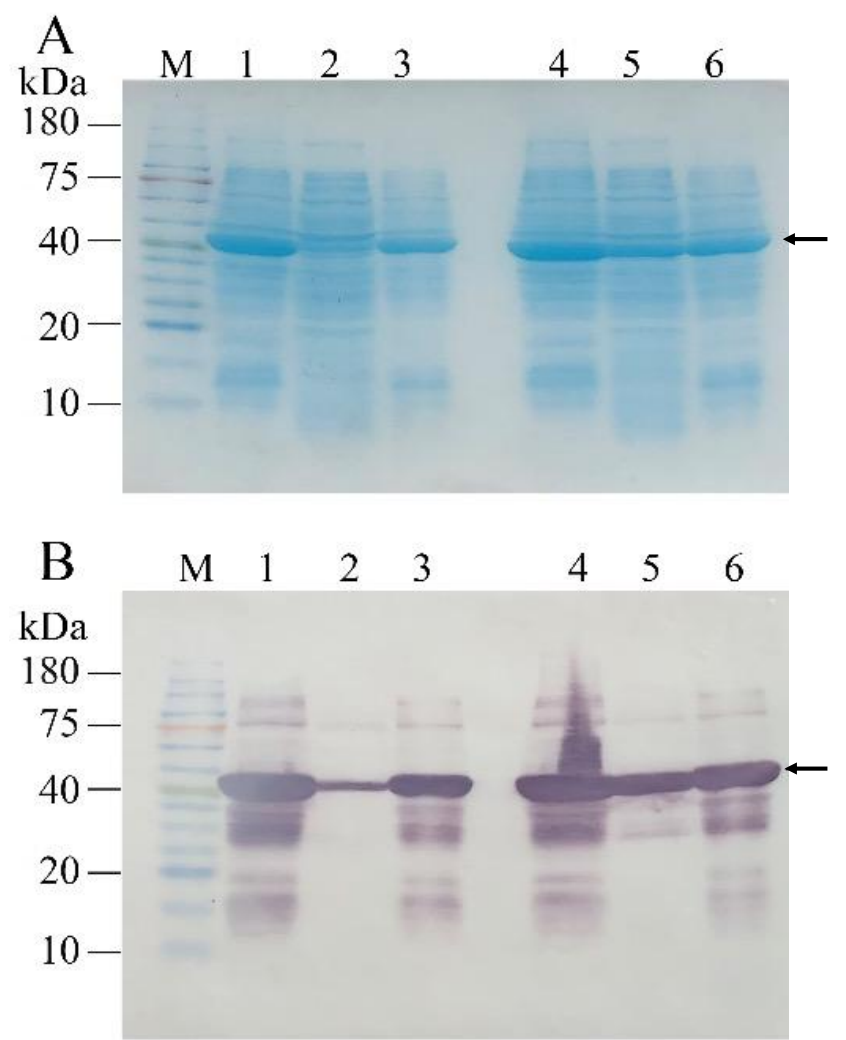

Figure 3 Soluble CHI 42 expression at $37^{\circ} \mathrm{C}$ vs. $30^{\circ} \mathrm{C}$. (A) SDS-PAGE and (B) Western blot made from the twin gel. Lane 1: total protein at $37^{\circ} \mathrm{C}$; lane 2: soluble fraction at $37^{\circ} \mathrm{C}$; lane 3: insoluble fraction at $37{ }^{\circ} \mathrm{C}$; lane 4: total protein at $30^{\circ} \mathrm{C}$; lane 5: soluble fraction at $30^{\circ} \mathrm{C}$; lane 6: insoluble fraction at $30^{\circ} \mathrm{C}$. Each temperature was analyzed with equivalent amounts of protein on equivalent lanes. The arrows indicate the expected positions of CHI42 on the gel and the membrane. 


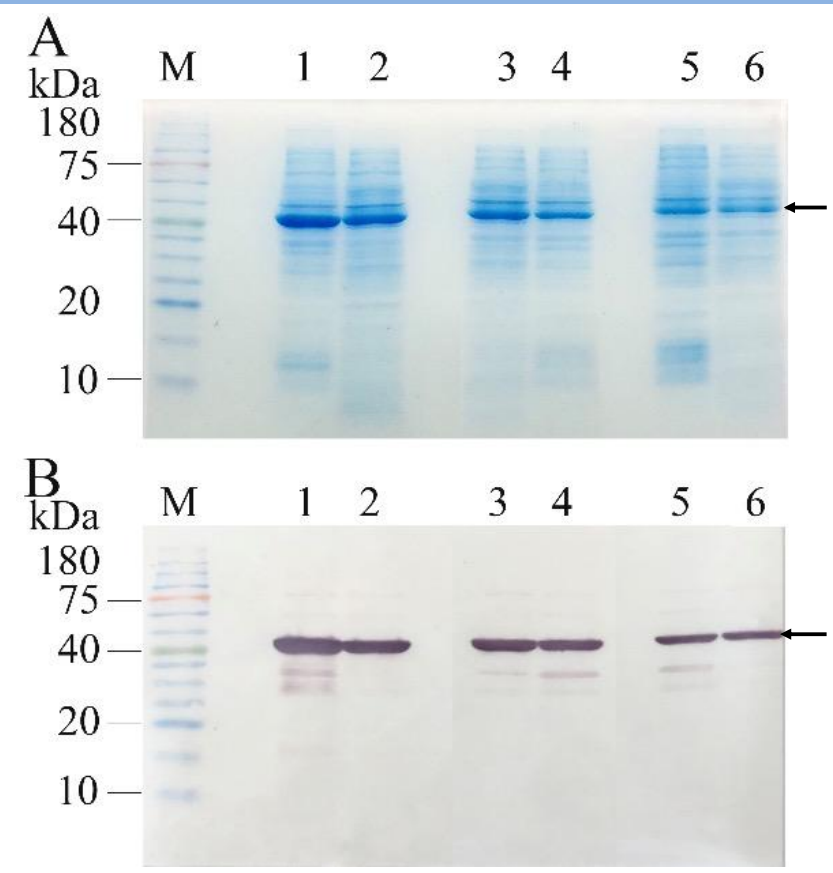

Figure 4 Optimizing induction temperatures for soluble CHI42 expression. (A) SDS-PAGE and (B) Western blot of the twin gel. Lane 1 and 2 are total protein and soluble fraction at $30^{\circ} \mathrm{C}$ induction, respectively; lane 3 and 4 are total protein and soluble fraction at $20{ }^{\circ} \mathrm{C}$; lane 5 and 6 are total protein and soluble fraction at $15^{\circ} \mathrm{C}$. Equal amounts of protein were loaded for each induction temperature. The arrows indicate the expected positions of $\mathrm{CHI} 42$.

Table 1 Proportion of soluble CHI42 vs total CHI42 at different induction temperatures and relative amount of soluble CHI42 at corresponding induction temperatures, with the amount of soluble $\mathrm{CHI} 42$ at $37^{\circ} \mathrm{C}$ set at $100 \%$

Induction temperatures $\%$ soluble CHI42 (normalized) against total CHI42

Relative amounts of soluble CHI42

\begin{tabular}{|lll|}
\hline $37^{\circ} \mathrm{C}$ & $14 \%$ & $100 \%$ \\
\hline $30^{\circ} \mathrm{C}$ & $40 \%$ & $588.2 \%$ \\
\hline $20^{\circ} \mathrm{C}$ & $49 \%$ & $247.0 \%$ \\
\hline $15^{\circ} \mathrm{C}$ & $53 \%$ & $152.9 \%$ \\
\hline
\end{tabular}

\subsection{Optimizing induction temperatures for soluble expression}

To maximize the amount of soluble CHI42, we surveyed two more induction temperatures: $20{ }^{\circ} \mathrm{C}$ and $15{ }^{\circ} \mathrm{C}$ degrees. Western blot analysis of the total soluble protein vs total protein indicated that lowering the temperature significantly improved the number of soluble CHI42 (Figure 4). In particular, at $20{ }^{\circ} \mathrm{C}$ and $15{ }^{\circ} \mathrm{C}$, the proportions of soluble $\mathrm{CHI} 42$ vs total expressed $\mathrm{CHI} 42$ increased from $40 \%$ to $49 \%$ and $53 \%$, respectively. However, in terms of absolute amount, induction at $30{ }^{\circ} \mathrm{C}$ yielded the highest amount of soluble CHI42 (Table 1).

Previous studies showed that one of the popular methods to improve the solubility of $E$. coli expressed proteins is to reduce induction temperatures (San-Miguel et al., 2013; Long et al., 2015; Nguyen et al., 2016; Nguyen et al., 2020). It is proposed that induction at low temperatures helps slow down the rate of protein synthesis and folding kinetics, as well as protein degradation due to the action of heat shock proteases. This significantly improves the solubility of the target proteins. However, the drawback of this method is that growth rates and thus protein yields may be severely affected (Costa et al., 2014). In this experiment, all of the above assessments held. The absolute amount of soluble CHI42 peaks at $30{ }^{\circ} \mathrm{C}$, although the proportion of soluble $\mathrm{CHI} 42$ maxes at $15{ }^{\circ} \mathrm{C}$.

\subsection{Purification and quantification of CHI42}

Based on our induction temperature survey result in this study, we proceeded to induce $\mathrm{CHI} 42$ expression at $30{ }^{\circ} \mathrm{C}$ for 4 hours. Purification of soluble CHI42 by gravity flow Ni-NTA column showed that the purification method could still be improved, as a significant 
amount of the target protein was lost in the washing fraction (Figure 5). This could be achieved by reducing the concentration of imidazole to $20 \mathrm{mM}-25 \mathrm{mM}$. The purity of CHI42 was determined to be approximately $90 \%$ based on SDS-PAGE analysis.

To estimate the yield of CHI42 based - on ELISA quantification, purified soluble CHI42 was used as standard to construct a standard curve (Figure 6). The soluble CHI42 accounted for 9\%$11 \%$ of total soluble protein. For $1 \mathrm{~L}$ culture, about $82-101 \mathrm{mg}$ of soluble CHI42 could be retrieved. A recent study showed the soluble recombinant human serum albumin expressed in E.coli has obtained approximately $9.46 \mathrm{mg}$ from a $500-\mathrm{mL}$ culture at $97 \%$ purity (Nguyen et al., 2020). ELISA-based yield seems underestimated as the SDS-PAGE analysis showed that soluble CHI42 might account for as much as $40 \%$ of total soluble protein. This could be due to the effect of polyclonal antibodies that were used in the ELISA assay. A monoclonal antibody would be ideal for the task.

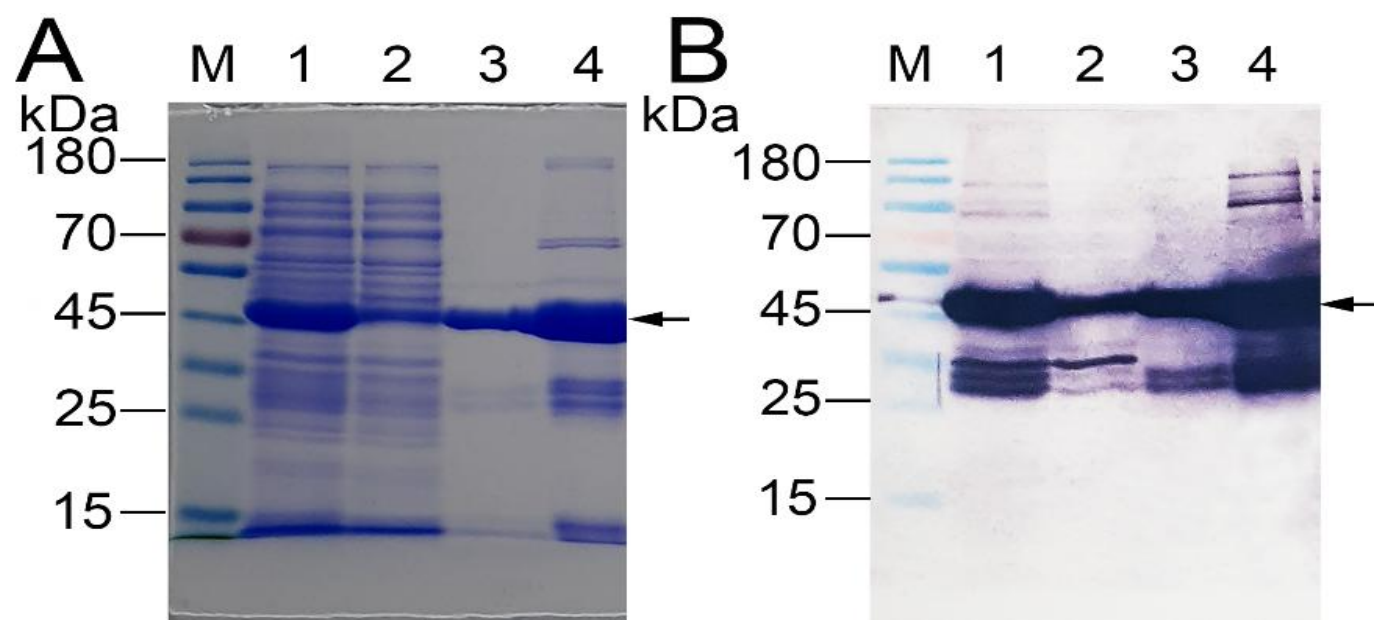

Figure 5 Purification of soluble CHI42 by Ni-NTA affinity chromatography. (A) SDS-PAGE analysis of the purification and (B) Western blot of the twin gel. Lane 1: total soluble protein; lane 2: flowthrough fraction; lane 3: washing and lane 4: elution fraction. Each lane was loaded with $2 \mu \mathrm{L}$ protein solution supplemented with $2 \mu \mathrm{L}$ of $6 \mathrm{x}$ loading buffer.

A

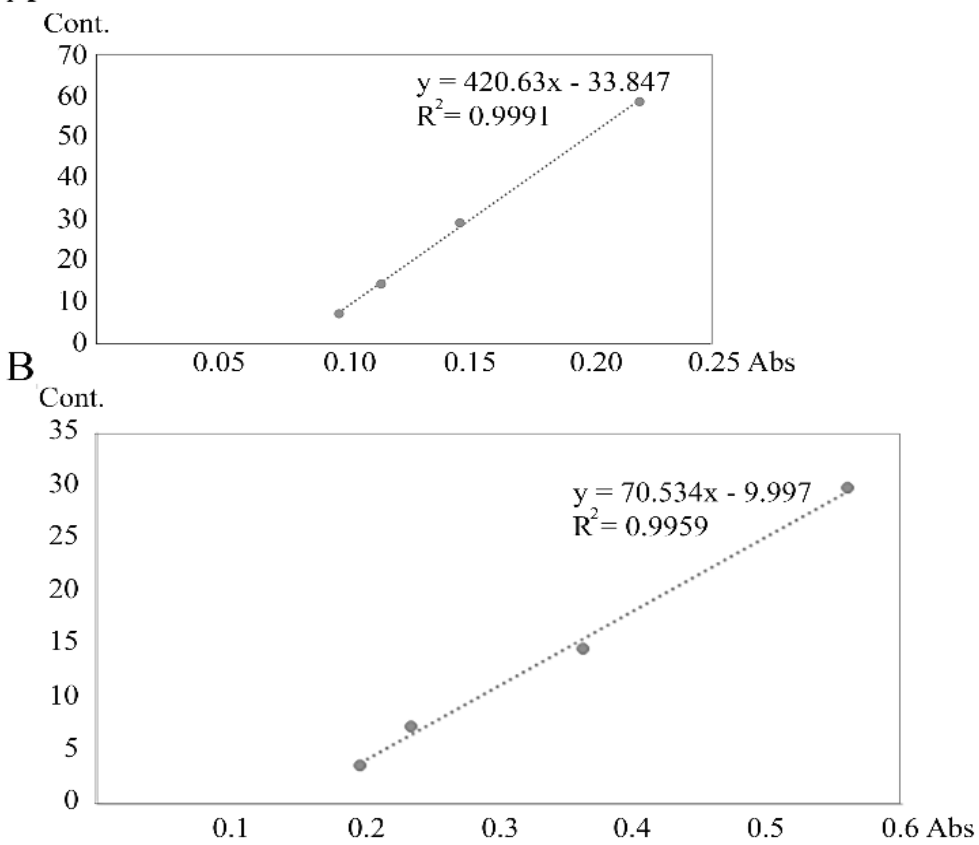

Figure 6 (A) standard curve of total soluble protein concentrations plotted against $\mathrm{OD}_{595}$ and (B) standard curve of purified CHI42 plotted against $\mathrm{OD}_{595}$. From this, the yield of soluble CHI42 was calculated.

Journal of Experimental Biology and Agricultural Sciences http://www.jebas.org 


\subsection{Analysis of purified soluble $42 \mathrm{kDa}$ chitinase activity}

The colloidal chitin hydrolysis of purified soluble CHI42 was shown on an agar plate (Figure 7). As expected, a clear zone, which is an indication of chitin hydrolysis, was not detected in the control pre-punched hole loaded with PBS. The clear zones were detected with statistically larger diameters than the ones loaded with the enzyme. The result indicated that the soluble $\mathrm{CHI} 42$ expressed in E.coli cells induced at $30{ }^{\circ} \mathrm{C}$ and $0.5 \mathrm{mM}$ IPTG folded in an active form at a high expression level and suggested that purified soluble had significant biological activity. Various previous studies showed that purified soluble heterologous proteins expressed in E. coli also had their biological activity (Long et al., 2015; Nguyen et al., 2016; Nguyen et al., 2020).

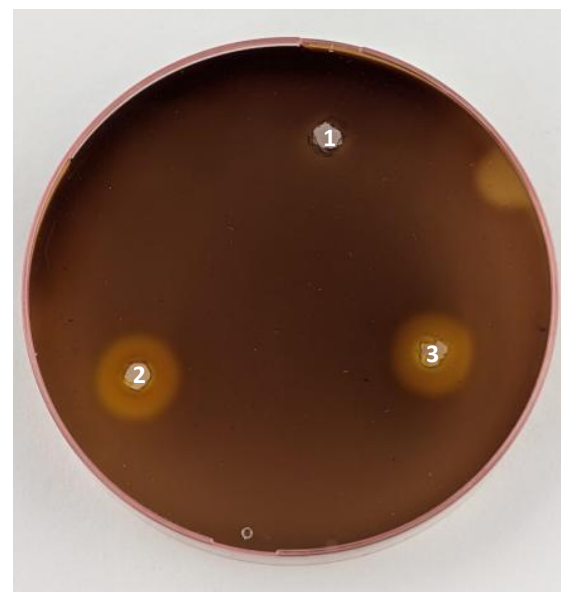

Figure 7 The chitinolytic activity of purified soluble CHI42 on $1.5 \%$ agar plate with $1.2 \%$ colloidal chitin as substrate. (1) prepunched hole loading with PBS as control and (2) (3) repeated assays loading with $300 \mu \mathrm{g}$ / hole of purified soluble CHI42.

Trichoderma spp. are often used as a fungal biocontrol in agriculture (Fenta et al., 2020; Poveda et al., 2020; Sood et al., 2020). However, other applications such as food spoilage prevention (Ramli et al., 2011) require more user-friendly forms. Recombinant chitinases from Trichoderma have been produced successfully in E. coli before (Ike et al., 2006; Klemsdal et al., 2006; Zeng et al., 2016; Deng et al., 2019) and this is a very economical method for mass production of these enzymes for agricultural or environmental applications. However, one of the biggest obstacles for enzyme production in E. coli has been obtaining a good expression level of soluble enzymes (Makrides, 1996), thus various strategies have been employed to improve the solubility of $E$. coli expressed proteins, including using different tags (SUMO, GST, MBP), lowering temperatures or co-expression of chaperones (Sørensen \& Mortensen, 2005; Mital et al., 2021). Among these strategies, lowering temperature is the most convenient method, but it does not guarantee that it always works. In this study, we were fortunate to obtain such a high level of expression with this simple strategy. Our result is apparently superior to several previous studies involving expressing $T$. chitinase in E. coli (Ike et al., 2006; Klemsdal et al., 2006; Sharma, 2012; Zeng et al., 2016).

\section{Conclusion}

In this work, the $w C H I 42$ gene (HM191683.1) from T. asperellum SH16 was redesigned, synthesized, and cloned into pQE30 to be expressed in E.coli M15 strains. The optimum soluble expression was achieved at $30^{\circ} \mathrm{C}$. The soluble enzyme could be conveniently purified using the gravity flow Ni-NTA column. The heterologous expression levels were estimated by SDS-PAGE and ELISA to be in the range of $10 \%-40 \%$ of total soluble protein. Finally, the purified soluble CHI42 showed chitin hydrolytic activity.

\section{Acknowledgments}

This work was supported by a grant from Hue University, Vietnam, under project code DHH2019-03-119. Phung Thi Bich Hoa was funded by Vingroup Joint Stock Company and supported by the Domestic Master/Ph.D. Scholarship Programme of Vingroup Innovation Foundation (VINIF), Vingroup Big Data Institute (VINBIGDATA), code [VINIF.2019.TS.27], [VINIF.2020.TS.111].

\section{Conflicts of interest}

All authors declare no conflicts of interest.

\section{References}

Costa S, Almeida A, CastroA, Domingues L (2014) Fusion tags for protein solubility, purification and immunogenicity in Escherichia coli: the novel Fh8 system. Frontiers in Microbiology 5(63). https://doi.org/10.3389/fmicb.2014.00063.

Deng JJ, Shi D, Mao HH, Li ZW, Liang S, Ke Y, Luo XC (2019) Heterologous expression and characterization of an antifungal chitinase (Chit46) from Trichoderma harzianum GIM 3.442 and its application in colloidal chitin conversion. International Journal of Biological Macromolecules 134: 113-121. https://doi.org/10.1016/ j.ijbiomac.2019.04.177.

Draborg H, Christgau S, Halkier T, Rasmussen G, Dalbøge H, Kauppinen S (1996) Secretion of an enzymatically active Trichoderma harzianum endochitinase by Saccharomyces cerevisiae. Current Genetics 29(4): 404-409. https://doi.org/10.1007/bf02208622.

Fenta L, Mekonnen H, Getnet T (2020) Biocontrol potential of trichoderma and yeast against post harvest fruit fungal diseases: A review. World News of Natural Sciences 27: 153-173. 
Hamid R, Khan MA, Ahmad M, Ahmad MM, Abdin MZ, Musarrat J, Javed S (2013) Chitinases: An update. Journal of Pharmacy and Bioallied Science 5(1): 21-29. https://doi.org/ 10.4103/0975-7406.106559.

Harman GE (2000) Myths and dogmas of biocontrol changes in perceptions derived from research on Trichoderma harzinum T-22. Plant Disease 84(4): 377-393. https://doi.org/10.1094/ pdis.2000.84.4.377.

Huy NX, Tien NQD, Kim MY, Kim TG, Jang YS, Yang MS (2016) Immunogenicity of an S1D epitope from porcine epidemic diarrhea virus and cholera toxin B subunit fusion protein transiently expressed in infiltrated Nicotiana benthamiana leaves. Plant Cell, Tissue and Organ Culture (PCTOC) 127(2): 369-380. https://doi.org/10.1007/s11240-016-1059-5.

Ike M, Nagamatsu K, Shioya A, Nogawa M, Ogasawara W, Okada $\mathrm{H}$, Morikawa Y (2006) Purification, characterization, and gene cloning of $46 \mathrm{kDa}$ chitinase (Chi46) from Trichoderma reesei PC3-7 and its expression in Escherichia coli. Applied Microbiology and Biotechnology 71: 294-303. https://doi.org/10.1007/s00253005-0171-y.

Jinzhu S, Qian Y, Beidong L, Dianfu C (2005) Expression of the chitinase gene from Trichoderma aureoviride in Saccharomyces cerevisiae. Applied Microbiology - Microbiology \& Biotechnology 69(1): 39-43. https://doi.org/10.1007/s00253-005-1957-7.

Johnson BH, Hecht MH (1994) Recombinant proteins can be isolated from $E$. coli cells by repeated cycles of freezing and thawing. Nature Biotechnology 12(12): 1357-1360. https://doi.org/10.1038/nbt1294-1357.

Kim TG, Huy NX, Kim MY, Jeong DK, Jang YS, Yang MS, Langridge WH, Lee JY (2009) Immunogenicity of a cholera toxin B subunit Porphyromonas gingivalis fimbrial antigen fusion protein expressed in E. coli. Molecular Biotechnology 41(2): 157 164. https://doi.org/10.1007/s12033-008-9102-3.

Klemsdal SS, Clarke JL, Hoell IA, Eijsink VGH, Brurberg MB (2006) Molecular cloning, characterization, and expression studies of a novel chitinase gene (ech30) from the mycoparasite Trichoderma atroviride strain P1. FEMS Microbiology Letters 256(2): 282-289. https://doi.org/10.1111/j.1574-6968.2006.00132.x.

Loc NH, Hoa NTQ, Cuc PTK, Quang HT (2013) Expression of chitinase (chi42) gene from Trichoderma asperellum in Saccharomyces cerevisiae. Annals of Biological Research 4(9): 15-19.

Loc NH, Quang HT, Hung NB, Huy ND, Phuong TTB, Ha TTT (2011) Trichoderma asperellum Chi42 Genes Encode Chitinase.
Mycobiology 39(3): 182-186. https://doi.org/10.5941/

MYCO.2011.39.3.182.

Long X, Gou Y, Luo M, Zhang S, Zhang H, Bai L, Wu S, He Q, Chen K, Huang A, Zhou J, Wang D (2015) Soluble expression, purification, and characterization of active recombinant human tissue plasminogen activator by auto-induction in E. coli. BMC Biotechnology 15: 13. https://doi.org/10.1186/s12896-015-0127-y.

Luong NN, Tien NQD, Huy NX, Tue NH, Man LQ, Sinh DDH, Thanh DV, Chi DTK, Hoa PTB, Loc NH (2021) Expression of $42 \mathrm{kDa}$ chitinase of Trichoderma asperellum (Ta-CHI42) from a synthetic gene in Escherichia coli. FEMS Microbiology Letters 368(16): https://doi.org/10.1093/femsle/fnab110.

Makrides SC (1996) Strategies for achieving high-level expression of genes in Escherichia coli. Microbiological Reviews 60(3): 512538. https://doi.org/10.1128/mr.60.3.512-538.1996.

Mastouri F, Björkman T, Harman GE (2010) Seed treatment with Trichoderma harzianum alleviates biotic, abiotic, and physiological stresses in germinating seeds and seedlings. Phytopathology 100(11): 1213-1221. https://doi.org/10.1094/ phyto-03-10-0091.

Mital S, Christie G, Dikicioglu D (2021) Recombinant expression of insoluble enzymes in Escherichia coli: a systematic review of experimental design and its manufacturing implications. Microbial Cell Factories 20(1): 208. https://doi.org/10.1186/s12934-02101698-w.

Morin-Crini N, Lichtfouse E, Torri G, Crini G (2019) Applications of chitosan in food, pharmaceuticals, medicine, cosmetics, agriculture, textiles, pulp and paper, biotechnology, and environmental chemistry. Environmental Chemistry Letters 17(4): 1667-1692.

Nguyen MT, Heo Y, Do BH, Baek S, Kim CJ, Jang YJ, Lee W, Choe H (2020) Bacterial overexpression and purification of soluble recombinant human serum albumin using maltose-binding protein and protein disulphide isomerase. Protein Expression and Purification 167: 105530. https://doi.org/10.1016/j.pep.2019.105530.

Nguyen MT, Krupa M, Koo BK, Song JA, Vu TT, Do BH, Nguyen AN, Seo T, Yoo J, Jeong B, Jin J, LeeKJ, Oh HB, Choe H (2016) Prokaryotic Soluble Overexpression and Purification of Human VEGF165 by Fusion to a Maltose Binding Protein Tag. PLoS ONE 11(5): e0156296. https://doi.org/10.1371/journal.pone.0156296.

Nguyen NL, Kim JM, Park JA, Park SM, Jang YS, Yang MS, Kim DH (2013) Expression and purification of an immunogenic dengue virus epitope using a synthetic consensus sequence of envelope domain 
III and Saccharomyces cerevisiae. Protein Expression Purification 88(2): 235-242. https://doi.org/10.1016/j.pep.2013.01.009.

Poveda J, Abril-Urias P, Escobar C (2020) Biological Control of PlantParasitic Nematodes by Filamentous Fungi Inducers of Resistance: Trichoderma, Mycorrhizal and Endophytic Fungi. Frontiers in Microbiology 11. https://doi.org/10.3389/fmicb.2020.00992.

Ramli AN, Mahadi NM, Rabu A, Murad AM, Bakar FD, Illias RM (2011) Molecular cloning, expression and biochemical characterisation of a cold-adapted novel recombinant chitinase from Glaciozyma antarctica PI12. Microbial Cell Factories 10: 94. https://doi.org/10.1186/1475-2859-10-94.

San-Miguel T, Pérez-Bermúdez P, Gavidia I (2013) Production of soluble eukaryotic recombinant proteins in $E$. coli is favoured in early log-phase cultures induced at low temperature. Springerplus 2(1): 89. https://doi.org/10.1186/2193-1801-2-89.

Schindelin J, Arganda-Carreras I, Frise E, Kaynig V, Longair M, Pietzsch T, Preibisch S, Rueden C, Saalfeld S, Schmid B, Tinevez JY, White DJ, Hartenstein V, Eliceiri K, Tomancak P, Cardona A (2012) Fiji: an open-source platform for biological-image analysis. Nature Methods 9(7): 676-682. https://doi.org/10.1038/nmeth.2019.

Seidl V, Huemer B, Seiboth B, Kubicek CP (2005) A complete survey of Trichoderma chitinases reveals three distinct subgroups of family 18 chitinases. The FEBS Journal 272(22): 5923-5939. https://doi.org/10.1111/j.1742-4658.2005.04994.x.

Seidl-Seiboth V, Ihrmark K, Druzhinina I, Karlsson M (2014) Chapter 5 - Molecular Evolution of Trichoderma Chitinases. In: Gupta VK, Schmoll M, Herrera-Estrella A, Upadhyay RS,
Druzhinina I, Tuohy MG (Eds.), Biotechnology and Biology of Trichoderma (pp. 67-78). Elsevier. https://doi.org/https://doi.org/ 10.1016/B978-0-444-59576-8.00005-9.

Sharma P (2012) Cloning and semi-quantitative expression of endochitinase (ech42) gene from Trichoderma spp. African Journal Of Biotechnology 11 (66): 12930-12938. https://doi.org/10.5897/ AJB11.3381

Shoresh M, Harman GE, Mastouri F (2010) Induced systemic resistance and plant responses to fungal biocontrol agents. Annual Review of Phytopathology 48: 21-43. https://doi.org/10.1146/annurev-phyto-073009-114450.

Sood M, Kapoor D, Kumar V, Sheteiwy MS, Ramakrishnan M, Landi M, Araniti F, Sharma A (2020) Trichoderma: The "Secrets" of a multitalented biocontrol agent. Plants (Basel) 9(6): 762. https://doi.org/10.3390/plants9060762.

Sørensen HP, Mortensen KK (2005) Advanced genetic strategies for recombinant protein expression in Escherichia coli. Journal of Biotechnology 115(2): 113-128. https://doi.org/10.1016/ j.jbiotec.2004.08.004

Trang NTN, Ha HTT, Thao NP, Tho DTA, Trang CT, Thanh LTH, Tue NH, Loc NH, Luong NN (2022) Expression of a synthetic gene encoding for the enhanced green fluorescent protein in various Escherichia coli strains. Vietnam Journal of Biotechnology 20(1) In Press.

Zeng R, Hu Q, Yin XY, Huang H, Yan JB, Gong ZW, Yang ZH (2016) Cloning a novel endo-1,4- $\beta$-D-glucanase gene from Trichoderma virens and heterologous expression in E. coli. AMB Express 6(1): 108-108. https://doi.org/10.1186/s13568-016-0282-0. 